\title{
Comparative Study of Removal of Heavy Metals from Industrial Wastewater Using Clay and Activated Carbon in Batch and Continuous Flow Systems
}

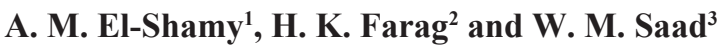 \\ ${ }^{1}$ Physical Chemistry Department, Electrochemistry and Corrosion Lab, National Re- \\ search Centre, 33 El Buhouth St., 12622 Dokki, Cairo, Egypt \\ ${ }^{2}$ Inorganic Chemistry Department, National Research Centre, 33 El Buhouth St., \\ 12622 Dokki, Cairo, Egypt \\ ${ }^{3}$ International Company for Chemical Industries, Plaza Tower, El Gaish St., El-Man- \\ soura, Daqahlyia, Egypt
}

\begin{abstract}
$\mathbf{T}$ HIS PAPER deals with the treatment of wastewater released from petroleum industry by using clay and activated carbon as adsorbents for removal of heavy metals. A filled column of clay and activated carbon was used for a continuous flow system and a sample collector was used to monitor the removal efficiency. The optimum treatment conditions were explored. The removal efficiencies of the heavy metal cations were found to be 55, 64, 75, 57, 63 , and $82 \%$ for $\mathrm{Pb}, \mathrm{Cu}, \mathrm{As}, \mathrm{Co}, \mathrm{Ni}$ and $\mathrm{Cr}$, respectively. After a second cycle of treatment, the removal efficiency was significantly increased. The removal efficiencies for the pretreated industrial samples were found to be 90, 99, 100, 100, 95 and $100 \%$ for $\mathrm{Cu}, \mathrm{As}, \mathrm{Co}, \mathrm{Ni}, \mathrm{Pb}$ and $\mathrm{Cr}$, respectively. These results indicate that the employed adsorbent mixture has a huge potential in the application as efficient adsorbent for removal of cationic heavy metal species from industrial wastewater.
\end{abstract}

Keywords: Wastewater treatment, Activated carbon, Clay mineral, Heavy metal ions, Batch and Continuous flow system.

\section{Introduction}

Environmental pollution by heavy metals is one of the serious problems resulting from many chemical industries. The quality of water is affected by discharging of heavy metals into water supply. The hazards of heavy metals are mainly due to their non-degradability and toxicity. The treatment of wastewater before discharging into municipal disposal is of a great concern for the protection of the environment from organic and inorganic compounds and heavy metals. The removal studies of pollutants from water mostly involve the adsorption of pollutants onto suitable adsorbents. Adsorption technique is effective and practical in the treatment of wastewaters containing pollutants owing to its high efficiency, simplicity and the availability of many adsorbents [1]. As known, activated carbon is one of the most widely utilized adsorbents for the adsorptive removal of organic compounds [2-5] and inorganic compounds [6] due to its large specific surface area and high adsorption capacity [7]. Activated carbon is the greatest important and lowpriced adsorbent, which is used in the existing contamination control. The Elais guineensis kernel activated carbon was used to remove copper [8]. The various parameters of Hevea brasiliensis bark carbon was studied for removing toxic metal ions $\mathrm{Ni}^{2+}, \mathrm{Cu}^{2+}$ and $\mathrm{Cd}^{2+}[9,10]$. Clay minerals are also regarded as key materials in reducing soil and water pollution $[11,12]$ by interacting with most soil contaminants [13]. Clay minerals and zeolites are considered as superior sorbents for remediation and removal of heavy metals [14-17]. The clay usually contains bacterial and/or fungal species, which are significant to assortment the biogeochemical series [18]. The negatively charged colloidal particles play an important role in the interaction of clay particles and cations

*Corresponding author e-mail: msherif888@yahoo.com 
[19-21]. Aluminosilicates with foliated texture, have usually negative surface charges, which have a good efficiency for capture of positive ions and therefore they are able to fixate $\mathrm{Ca}^{2+}$, $\mathrm{Mg}^{2+}, \mathrm{K}^{+}, \mathrm{Na}^{+}, \mathrm{Al}^{3+}, \mathrm{Mn}^{2+}$ cations and ammonium nitrogen [22-24]. Industrial effluents can usually contain more than one heavy metal species, so the behavior of metal species in wastewater might be influenced by the existence of additional metals. The aim of this study is to examine the removal of some heavy metals from industrial effluents using clay minerals and activated carbon. The optimum conditions of the treatment regime will be demonstrated.

\section{Materials and Methods}

\section{Materials \\ Adsorbent material}

The clay-based adsorbent materials are collected from the northeastern Nile Delta of Egypt.The clay was prepared by air drying and crushing by using mortar and pestle and it was sieved by passing through a 60 -mesh sieve. The physical and chemical analyses of the studied soils and collected water samples were carried out according to Klute [25]. Laboratory grade granular activated carbon of plant origin was used as adsorbent. Directly before use, it was grinded using a mortar and a pestle and then passed through a 60-mesh sieve.

\section{Chemicals}

The stock solution of heavy metals was prepared by dissolving $1.0 \mathrm{~g}$ of each $\mathrm{CuSO}_{4} .5 \mathrm{H}_{2} \mathrm{O}$, $\mathrm{CoSO}_{4} \cdot 7 \mathrm{H}_{2} \mathrm{O}, \quad \mathrm{NiSO}_{4} \cdot \mathrm{XH}_{2} \mathrm{O}, \mathrm{AsSO}_{4}, \mathrm{PbSO}_{4}$ and $\mathrm{K}_{2} \mathrm{Cr}_{2} \mathrm{O}_{7}$ in $1 \mathrm{~L}$ of solution. The required concentrations of heavy metals were prepared by dilution series using distilled water. The prepared solutions were subjected to vigorous shaking for about 2 hours using orbital incubator shaker at $30^{\circ} \mathrm{C}$ and $100 \mathrm{rpm}$ to ensure homogeneity. Concentrated nitric acid $(63 \%, \mathrm{w} / \mathrm{w})$ and sodium hydroxide pellets were used to adjust the $\mathrm{pH}$. All chemicals were of high-grade quality from Merck, $\mathrm{BDH}$ and Fisher companies.

\section{Methods \\ Instrumentations}

An atomic absorption spectrometer (AAS), type AA-6800, Shimadzo, Japan, with heavy metals hallow cathode lamp and air acetylene flame was used to determine the heavy metal concentrations. A $\mathrm{pH}$ meter was used for $\mathrm{pH}$ measurement, and before measurements it was calibrated by using buffer solutions with different $\mathrm{pH}$ values, 4.01, 6.86 and 9.18. A mechanical shaker was utilized for agitating the samples.

\section{Activated carbon preparation}

The carbon was activated using $\mathrm{H}_{3} \mathrm{PO}_{4}$ in one-step chemical activation. An appropriate amount of the used carbon was soaked in $85 \%$ (w/w) $\mathrm{H}_{3} \mathrm{PO}_{4}$ and the volume of $\mathrm{H}_{3} \mathrm{PO}_{4}$ was high enough to completely cover the used carbon. The system was slightly agitated to ensure complete penetration of the acid throughout the carbon granules. The mixture was heated to $80^{\circ} \mathrm{C}$ for one hour and was left over night at room temperature to enable wetting and impregnation of the carbon. The impregnated carbon was dried in an oven at $80^{\circ} \mathrm{C}$ overnight, then placed in an electric furnace and the temperature raised at a rate of $10^{\circ} \mathrm{C} / \mathrm{min}$ up to $500{ }^{\circ} \mathrm{C}$. The temperature was then maintained at $500{ }^{\circ} \mathrm{C}$ for 2.5 hours. The product was washed thoroughly with hot distilled water until reaching a $\mathrm{pH} 5$ and finally dried at $110{ }^{\circ} \mathrm{C}$ and then, grinded and sieved using a 60-mesh sieve [26].

\section{Batch adsorption experiments}

Batch adsorption experiments were carried out in a series of reagent bottles. $50 \mathrm{ml}$ of heavy metal solution with initial concentrations of 25 , $50,75,100,125$ and $150 \mathrm{ppm}$ were put inside $100 \mathrm{ml}$ reagent bottles, which contained $5 \mathrm{~g}$ of clay and $2 \mathrm{~g}$ of activated carbon. The $\mathrm{pH}$ of the synthetic solution was adjusted to the desired values prior to experiments by adding $\mathrm{HNO}_{3}$ or $\mathrm{NaOH}$. The reagent bottles were shaked using an incubating shaker, which operated at $50 \mathrm{rpm}$ and $25^{\circ} \mathrm{C}\left( \pm 2{ }^{\circ} \mathrm{C}\right)$ for $30 \mathrm{~min}$ to attain the equilibrium condition. Blank experiment was treated similarly without the adsorbent mixture, and the recorded concentrations at the end of each operation were taken as the initial. The final concentrations of the solution were then determined from a calibration curve. The removal efficiency is calculated according to the following equation :

Removal efficiency $\%=\frac{\text { Initial concentration }- \text { Final concentration }}{\text { Initial concentration }} \mathrm{x} 100$

\section{Continuous flow adsorption experiments}

The sodium alginate was used to prepare the coated billets of activated carbon and clay to be used in the continuous flow experiment. $50 \mathrm{~mL}$ sodium alginate solution (4\%) was added drop wise to a mixture of clay and activated carbon, $10 \mathrm{~g}$ suspended in $50 \mathrm{ml}$ of distilled water, during stirring. The suspension was stirred for an 
additional period of $20 \mathrm{~min}$, then left to stand for 30 min to allow air bubbles to escape. The mixture was extruded dropwise via $5 \mathrm{ml}$ syringe from a height of about $20 \mathrm{~cm}$ into $1 \mathrm{~L}$ of $0.2 \mathrm{M} \mathrm{CaCl}_{2}$. The beads of calcium alginate entrapped cells were left to harden in $\mathrm{CaCl}_{2}$ solution for about $20 \mathrm{~min}$ the prepared immobilized mixture was introduced to the column and the prepared heavy metal solution was pumped at different flow rates to determine the duration time of breakthrough.

Removal of heavy metals from industrial effluents

The samples were collected from petroleum companies with respect to Ultra extract Company for water and wastewater treatment. The Ultra extract Company for water and wastewater treated the collected samples by chemical treatments in multi-stages. These samples were subjected to chemical analysis before and after treatment. It is found that the chemically treated samples still have high concentrations of heavy metals. These treated samples were subjected to the physical treatment by using the adsorbent mixture of clay and activated carbon.

\section{Results and Discussion}

The texture of clay-based adsorbent material

Table 1 illustrates the clay texture in categorizing the major arrangement of adsorbent material and as well as the mineralogical analysis. The grain size dissemination test is determined according to DIN, 18123 [27] and BS, 1377 [28]. The particle size distribution of clayey soil is achieved by using both wet sieving and sedimentation analysis. As mentioned in Table 1 , the studied adsorbent material includes 53\%, $43 \%$ and $4 \%$ of silt, clay and sand respectively and these constituents prove that the adsorbent material could be classified as clayey silt type.

The mineralogy of clay-based adsorbent

The X-ray diffraction analysis (XRD) is

TABLE 1. The clay-based adsorbent materials and its mineralogical analysis.

\begin{tabular}{llll}
\hline \multicolumn{2}{c}{ Clay-based adsorbent materials } & \multicolumn{2}{c}{ Mineralogical analysis } \\
\hline Clayey soil fractions & Percent (\%) & Type of clay mineral & Percent (\%) \\
Gravel & 0.0 & Illite/smectite mixed layer & $8.0 \pm 2.0$ \\
Sand & $4.0 \pm 0.4$ & Illite & $68.0 \pm 5.0$ \\
Silt & $53.0 \pm 0.7$ & Kaolinite & $24.0 \pm 4.0$ \\
Clay & $43.0 \pm 1.1$ & & \\
\hline
\end{tabular}

carried out to identify mineralogical analysis of clay-based adsorbent. According to the XRD chart the tested adsorbent material shows that presence of the following percentages $(8 \%),(68 \%)$ and (24\%) for illite-smectite mixed layer, illite and kaolinite respectively, see (Table 1).

\section{Effect of initial $\mathrm{pH}$}

Figure 1 shows the effect of the $\mathrm{pH}$ on the removal efficiencies of heavy metals from the polluted aqueous solution. The obtained results reveal that the removal efficiency of the heavy metals increases with the increase in the $\mathrm{pH}$ and the maximum efficiencies are obtained in the $\mathrm{pH}$ range of 6 to 8 . The obtained results are in a good agreement with the most cited literature and the best range of $\mathrm{pH}$ was found to be 6.8 to 7.4 . The results indicate a minimum adsorption efficiency of heavy metals at low $\mathrm{pH}$ as previously reported [8]. Compared with the heavy metal ions, the high concentration and mobility of the small sized hydrogen ions $\left(\mathrm{H}^{+}\right)$favor the interaction with negative sites at adsorbent materials at low $\mathrm{pH}$ values. Consequently, the superficial of the adsorbent is bounded by hydronium ions $\left(\mathrm{H}_{3} \mathrm{O}^{+}\right)$, which prevent the connection of metal ions with the binding sites of the sorbent materials. This means that at higher hydrogen ion concentrations, the surface of the sorbent materials becomes more positively charged, which reduce the attraction between sorbent materials and metal cations. On the other hand, at high $\mathrm{pH}$ values the sorbent surface becomes more negatively charged, facilitating the attachment with heavy metal cations, which leads to an increased removal efficiency. The obtained results suggest that the cations species of heavy metals are adsorbed at the surface of adsorbent materials by ion exchange mechanism, which is concerned with the functional groups present in adsorbent materials and in the same time it might also be occurred through hydrogen bonding mechanism. 


\section{Effect of adsorbent dosage}

Figure 2 illustrates the effect of clay weight ( $g$ ) on the removal efficiency of heavy metals and shows the mass capacity relationship. The capacity of the adsorbent dosage depends on the kind of adsorbent materials and its surface nature, which encouragements the amount of metal cations removal from the solution. The obtained results show that the amount of metal uptake increases with increasing of adsorbent weight until about $5 \mathrm{~g}$ of the adsorbent materials. A further increase in the weight of the absorbent does not lead to a subsequent increase of the amount of metal uptake. This can be described by the available limit of the adsorbing materials compared with the relatively large number of surface sites on the adsorbent at higher dosages of adsorbent. It was found that the influence of adsorbent mass is directly proportional to the heavy metal removal $[29,30]$. It is believable that with higher dosages of adsorbent materials, there would be greater accessibility of replaceable active sites from metal ions due to the increase of surface area [31]. The decrease in the dosages of the adsorbent materials at certain metal concentration enhances the metal/adsorbent ratio, and thus increases the metal uptake per unit area of adsorbent, as long as the latter is not saturated. The adsorption capacity

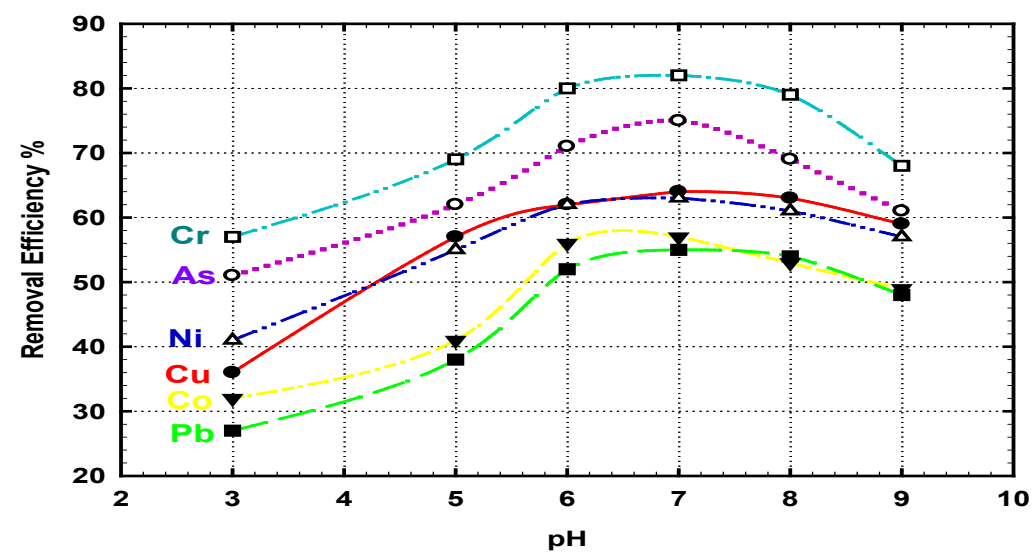

Fig. 1. Effect of $\mathbf{p H}$ on the removal efficiency of heavy metals by $\mathbf{5} \mathrm{g}$ clay $+\mathbf{2} \mathrm{g}$ activated carbon mixed in $\mathbf{5 0}$ $\mathrm{ml}$ of $100 \mathrm{ppm}$ initial concentration of heavy metals, shaking off $30 \mathrm{~min}$ at $50 \mathrm{rpm}$, incubated at room temperature $25 \pm 2^{\circ} \mathrm{C}$.

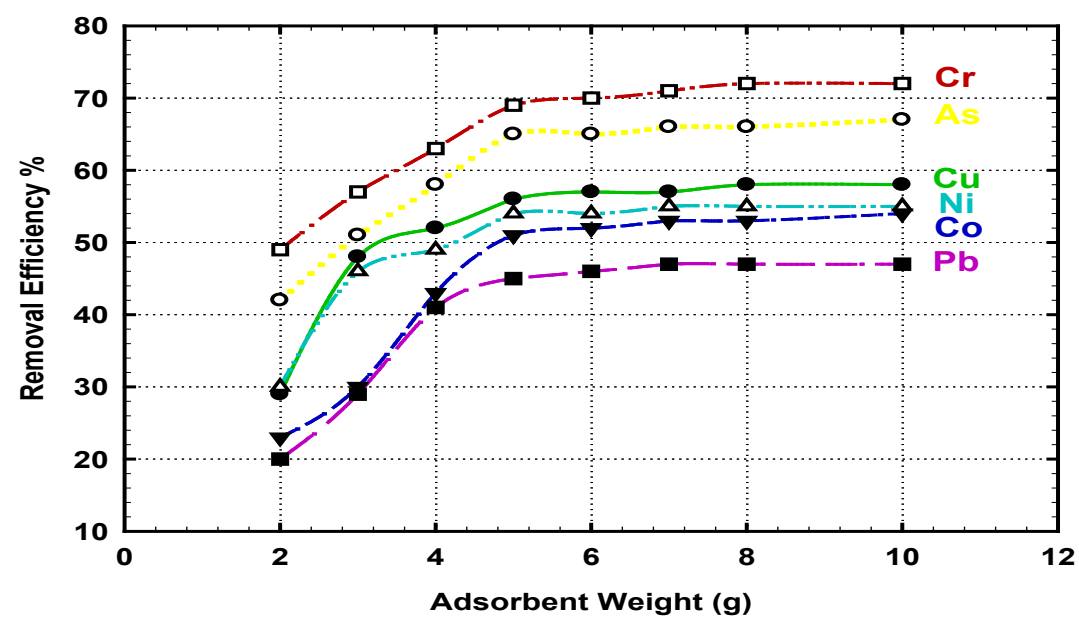

Fig. 2. Effect of clay weight (g) on the removal efficiency of heavy metals in $50 \mathrm{ml}$ of $100 \mathrm{ppm}$ initial concentration at $\mathrm{pH} 7$, shaking off $30 \mathrm{~min}$ at $50 \mathrm{rpm}$, incubated at room temperature $25 \pm 2^{\circ} \mathrm{C}$. 
decreases with increasing adsorbent dosage. This might be attributed to touching the adsorption sites because of overcrowding the adsorbent particles. In addition, the high adsorbent quantity could force the selection effect and dense the uptake of the outer layer of adsorbent materials, thereby defensive the binding sites from metal.
Figure 3 shows the effect of the presence of activated carbon on the removal efficiency of clay mineral. The synergistic effect of the adsorbent mixture is clearly noticed from the obtained results. The removal efficiency of heavy metals increases by increasing the activated carbon dosage till $2 \mathrm{~g}$. This dosage was selected to carry out all experiments because increasing the dosage

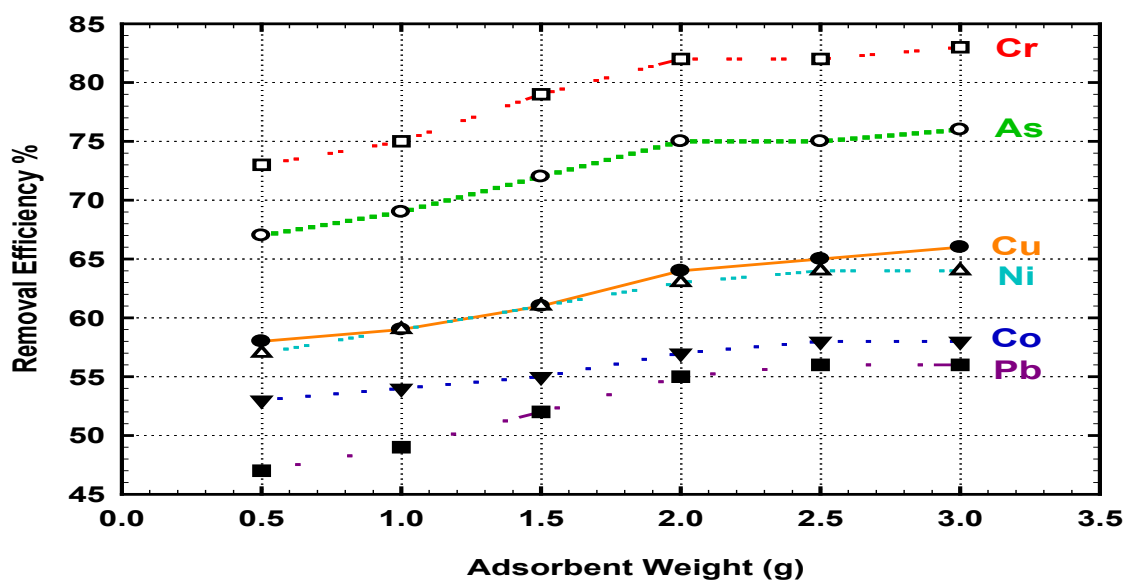

Fig. 3. Effect of activated carbon weight (g) mixed with $5 \mathrm{~g}$ clay on the removal efficiency of heavy metals in $50 \mathrm{ml}$ of $100 \mathrm{ppm}$ initial concentration at $\mathrm{pH} 7$, shaking of $30 \mathrm{~min}$ at $50 \mathrm{rpm}$, incubated at room temperature $25 \pm 2^{\circ} \mathrm{C}$.

of activated carbon more than $2 \mathrm{~g}$ does not lead to a further improvement in the removal efficiency. The above results reveal that the optimum dosages from clay and activated carbon are $5 \mathrm{~g}$ and $2 \mathrm{~g}$, respectively, which mean that the minimum mass dosage with highest removal efficiency.

\section{Effect of application time}

Figure 4 displays the effect of contact time on the removal efficiency of heavy metals using a mixture of clay and activated carbon. The obtained results show that the removal efficiency of heavy metals increases with increasing the contact time and the highest removal efficiency is obtained at 30

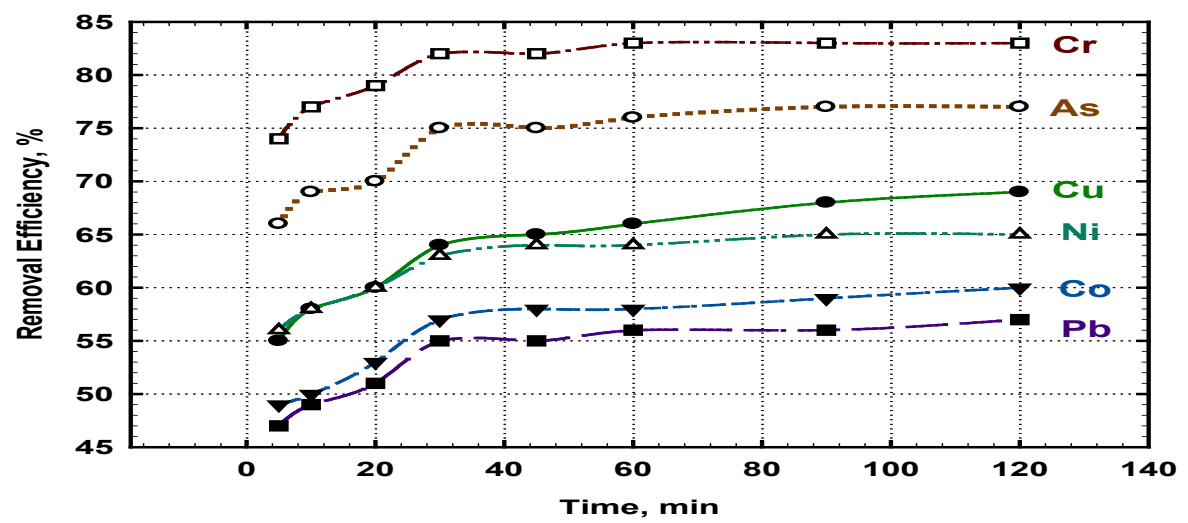

Fig. 4. Effect of application time on the removal efficiency of heavy metals by $5 \mathrm{~g}$ clay $+2 \mathrm{~g}$ activated carbon mixed in $50 \mathrm{ml}$ of $100 \mathrm{ppm}$ initial concentration of heavy metals, shaking of $30 \mathrm{~min}$ at $50 \mathrm{rpm}$, incubated at room temperature $25 \pm 2^{\circ} \mathrm{C}$. 
minutes of contact time. The removal efficiencies of $\mathrm{Pb}, \mathrm{Cu}, \mathrm{As}, \mathrm{Co}, \mathrm{Ni}$ and $\mathrm{Cr}$ are 55, 64, 75, 57, 63 , and $82 \%$, respectively, at this time. Thus, the optimum contact time was found to be 30 minutes. The short time of removal of heavy metals suggests that the type of adsorption could be chemical adsorption, which extinguishable as fast attack between heavy metals and adsorbent surface.

\section{Effect of initial adsorbate concentration}

Figure 5 shows the effect of initial concentration

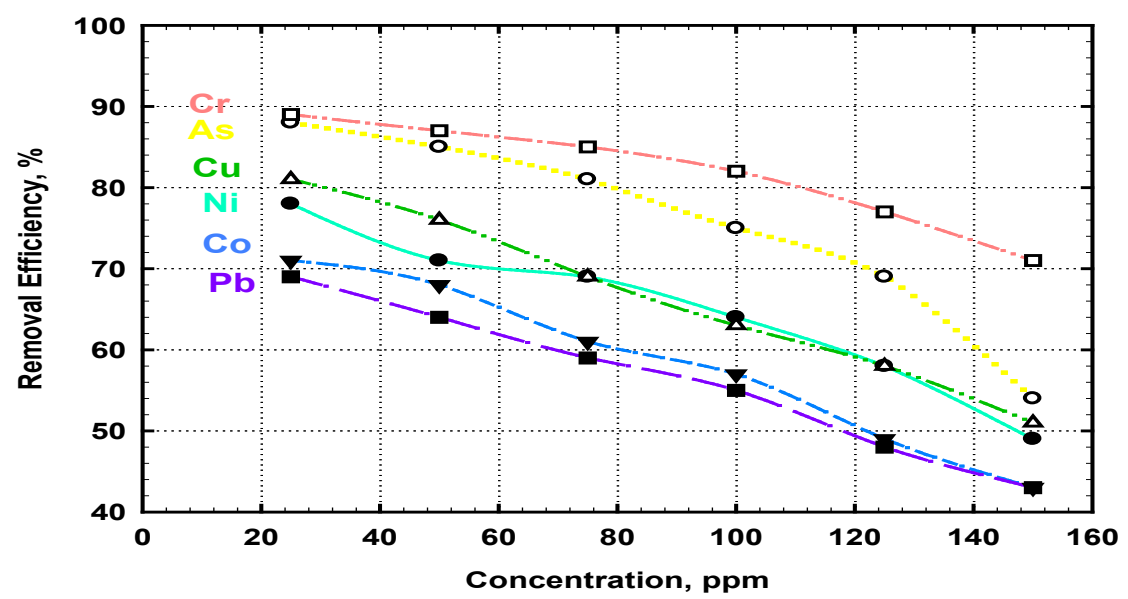

Fig. 5. Effect of concentration of heavy metals on the removal efficiency of heavy metals by $5 \mathrm{~g}$ clay $+2 \mathrm{~g}$ activated carbon mixed in $50 \mathrm{ml}$ of $100 \mathrm{ppm}$ initial concentration of heavy metals, shaking of $30 \mathrm{~min}$ at $50 \mathrm{rpm}$, incubated at room temperature $25 \pm 2^{\circ} \mathrm{C}$.

of heavy metals on the removal efficiencies. Although the removal efficiency decreases by increasing heavy metal concentrations, the metal uptake increases with the concentration. The initial concentration of $100 \mathrm{ppm}$ was selected to be the main concentration for carrying out all experiments as it gives the best results for mass capacity.
Heavy metal removal in a continuous flow system

A glass column was packed with the immobilized mixture of adsorbent materials in billets form and the column was adjusted for flow rate $5 \mathrm{ml}$ per $\min (300 \mathrm{ml}$ per hour). The fraction collector was adjusted for collecting samples and the samples were collected every 5 min. Fig. 6 exemplifies the results of heavy metal uptake in a continuous flow system and the breakthrough of

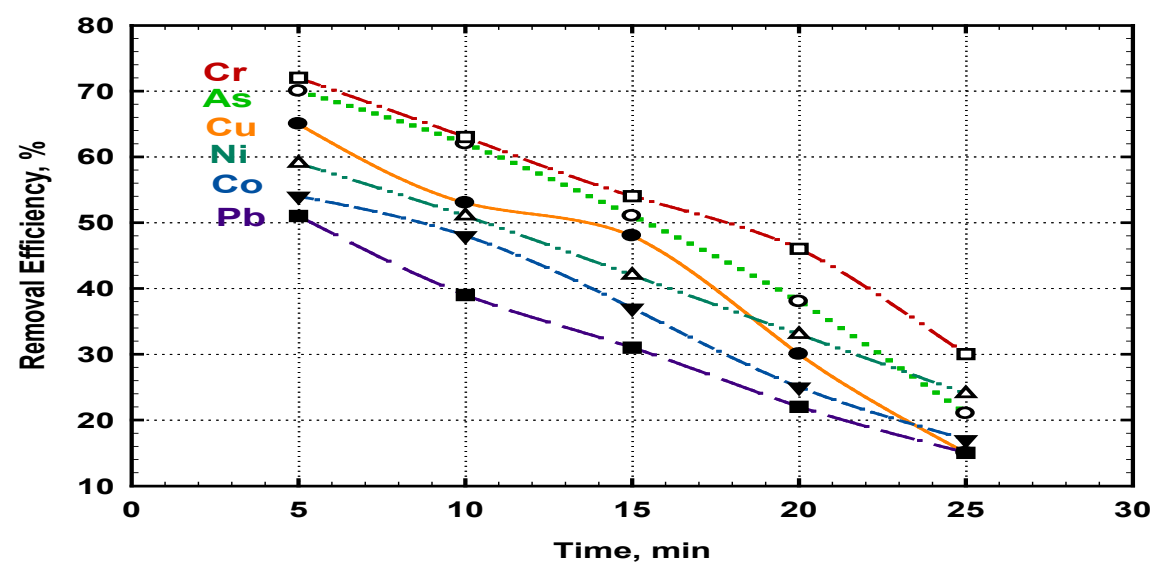

Fig. 6. Heavy metal uptake in continuous flow system at $100 \mathrm{ppm}$ initial concentration of heavy metals and flow rate $5 \mathrm{ml}$ per min. by immobilized adsorbent mixture of $10 \mathrm{~g}$ clay and $4 \mathrm{~g}$ of activated carbon. 
the column was determined. The obtained results showed that the removal efficiency decreases with time due to the saturation of the adsorbent materials with heavy metals. It is clear that the breakthrough of the column can be achieved in 30 minutes and these problems can be improved through increasing the diameter and height of the used column.

\section{Heavy metals removal from industrial effluents}

Figure $7 \mathrm{a}$ illustrates the results obtained from the treatment by adsorbent mixtures of clay minerals and activated carbon for one water sample

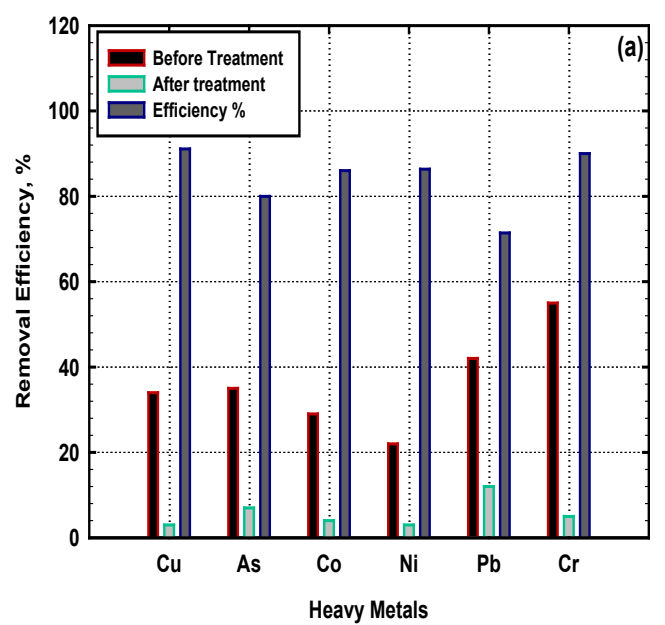

Fig. 7a. Treatment of petroleum industrial effluents by adsorbent mixture of clay minerals and activated carbon, first stage treatment.

Figure $7 \mathrm{~b}$ shows the obtained results from the second treatment regime that clearly reveal the high efficiency of the employed treatment regime of industrial polluted water. The efficiencies for $\mathrm{Cu}, \mathrm{As}, \mathrm{Co}, \mathrm{Ni}, \mathrm{Pb}$ and $\mathrm{Cr}$ sample are 90, 99, 100, 100, 95 and $100 \%$ respectively. These results are acceptable and agree with the recommended concentration of standard concentration of heavy metals in disposal water.

\section{Interaction between clay minerals and heavy metals}

Clays and clay minerals are used for a wide range of environmental applications such as waste management, water sanitization, mineral barriers for waste deposits and slurry walls for the capsulation of polluted areas. This is due to their huge definite surfaces and its capability to adsorb cations [32]. The general formula of clay minerals is characterized by illite $\left(\mathrm{K}_{3} \mathrm{H}_{3} \mathrm{O}\right)(\mathrm{Al}$, $\mathrm{Mg}, \mathrm{Fe})_{2}(\mathrm{Si}, \mathrm{Al})_{4} \mathrm{O}_{10}\left[(\mathrm{OH})_{2},\left(\mathrm{H}_{2} \mathrm{O}\right)\right]$ and muscovite of petroleum effluents. The removal efficiencies for heavy metals for one-stage treatment are 91.1, 80, 86, 86.36, 71.42 and $90 \%$ for $\mathrm{Cu}, \mathrm{As}, \mathrm{Co}$, $\mathrm{Pb}$, and $\mathrm{Cr}$ respectively. Although the obtained removal efficiencies are good, the residual concentrations of heavy metals are still higher than the standard acceptable concentrations. The obtained sample from this step was re-subjected to a further treatment by the adsorbent mixture to improve the efficiency to reach acceptable values, which agree with the recommendation of environmental protection agency.

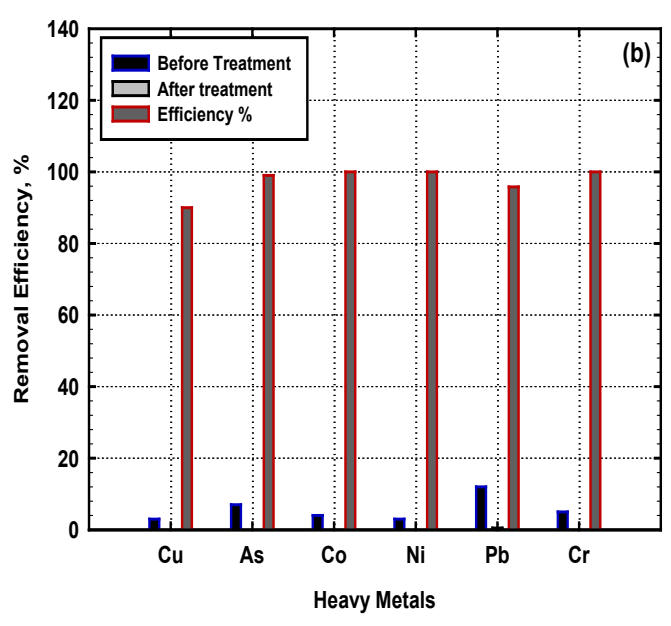

Fig. 7b. Treatment of petroleum industrial effluents by adsorbent mixture of clay minerals and activated carbon, second stage treatment.

$\mathrm{KAl}_{2}\left(\mathrm{AlSi}_{3} \mathrm{O}_{10}\right)(\mathrm{FOH})_{2}$, kaolinite $\mathrm{Al}_{2} \mathrm{Si}_{2} \mathrm{O}_{5}(\mathrm{OH})_{4}$, as well as smectite and chlorite mixtures [23]. The sorption capability of natural sorbent materials in separate samples is reasonably multifaceted problem and the understanding of these data is very indistinct. The clay minerals are the most important natural sorbents and the heavy metals mobility in nature is determined by their solubility and sorption ability [33]. In case of clay minerals, the dominant process is represented by ionic replacement between solution and solid phase but partially also physical process of adsorption [22].

\section{Adsorption isotherm}

The capability of the adsorption isotherm is necessary, and plays an important role in the identification and evaluation the extreme capacity of adsorption process. It also offers an outlook of the progression of uptake by the adsorbent materials under study in summarizing form. In addition, it allows an assessment of the commercial 
feasibility of the industrial applications. Several mathematical models such as Freundlich isotherm can describe the adsorption isotherm as follows:

$$
\mathrm{C}_{\mathrm{o}}-\mathrm{C}_{\mathrm{e}} / \mathrm{m}=\mathrm{K} \cdot \mathrm{C}_{\mathrm{e}}{ }^{1 / \mathrm{n}}
$$

This equation can be rearranged and linearized in the following formula:

$$
\log \left(\mathrm{C}_{\mathrm{o}}-\mathrm{C}_{\mathrm{e}} / \mathrm{m}\right)=\log \mathrm{K}+1 / \mathrm{n} \log \mathrm{C}_{\mathrm{e}}
$$

Where $\mathrm{C}_{\mathrm{o}}$ is the initial concentration (ppm),

TABLE 2. Freundlich adsorption equations and constants $(\log k$ and $n)$ for metal cations on bentonitic clay.

\begin{tabular}{cccc}
\hline Metal & $\log \mathbf{k}(\mathbf{m g} / \mathbf{g})$ & $\mathbf{1 / n}$ & $\mathbf{R}^{\mathbf{2}}$ \\
\hline $\mathrm{Cu}^{2+}$ & 0.54 & 1.83 & 0.9779 \\
$\mathrm{Ni}^{2+}$ & 0.48 & 1.52 & 0.9869 \\
$\mathrm{As}^{2+}$ & 0.28 & 1.28 & 0.9713 \\
$\mathrm{Co}^{2+}$ & 0.7 & 1.91 & 0.9722 \\
$\mathrm{~Pb}^{2+}$ & 0.8 & 1.96 & 0.9835 \\
$\mathrm{Cr}^{2+}$ & 0.24 & 1.25 & 0.9845 \\
\hline
\end{tabular}
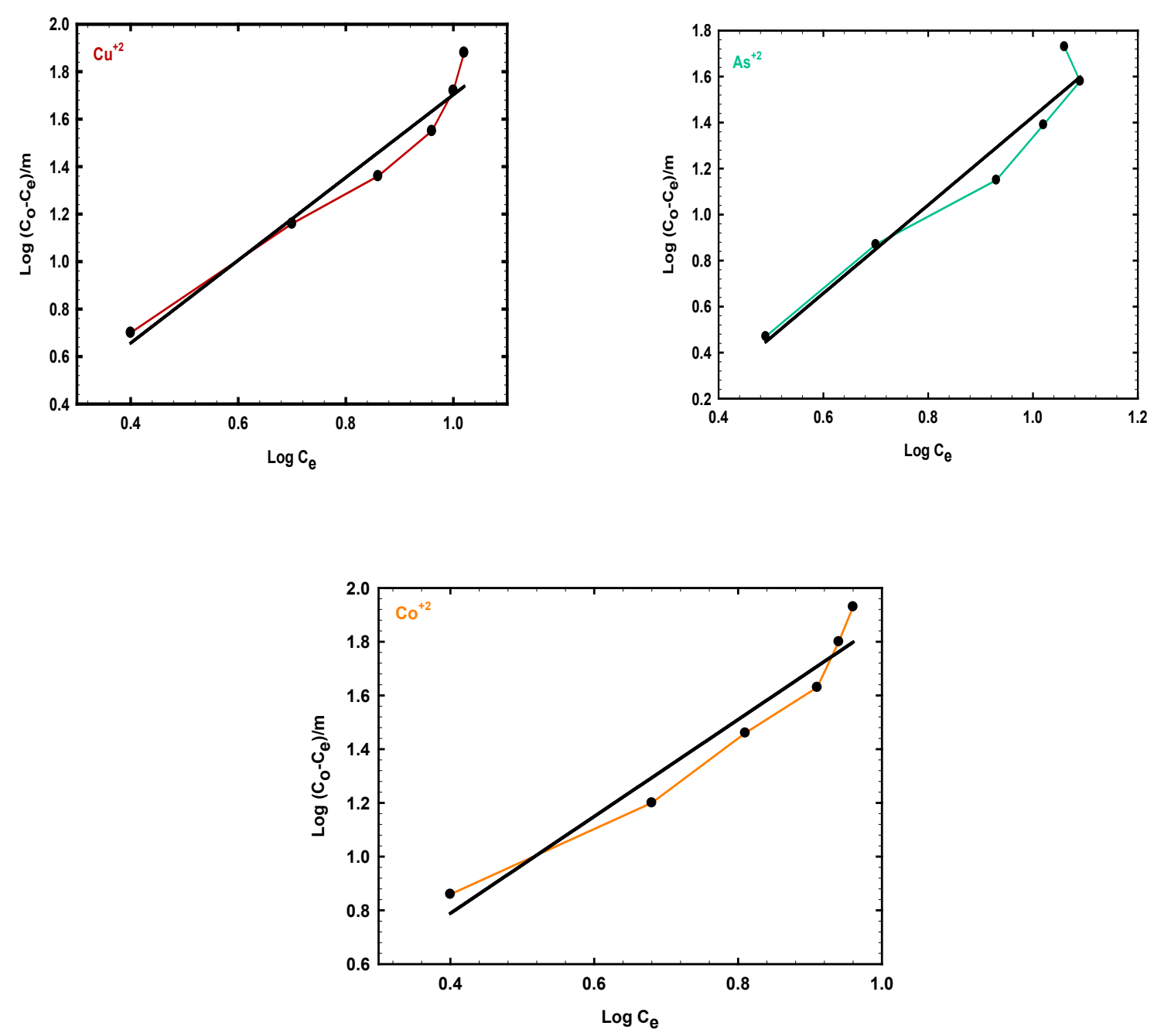

Fig. 8a. The Freundlich Isotherm for $\mathrm{Cu}$, As, and $\mathrm{Co}$, respectively. 

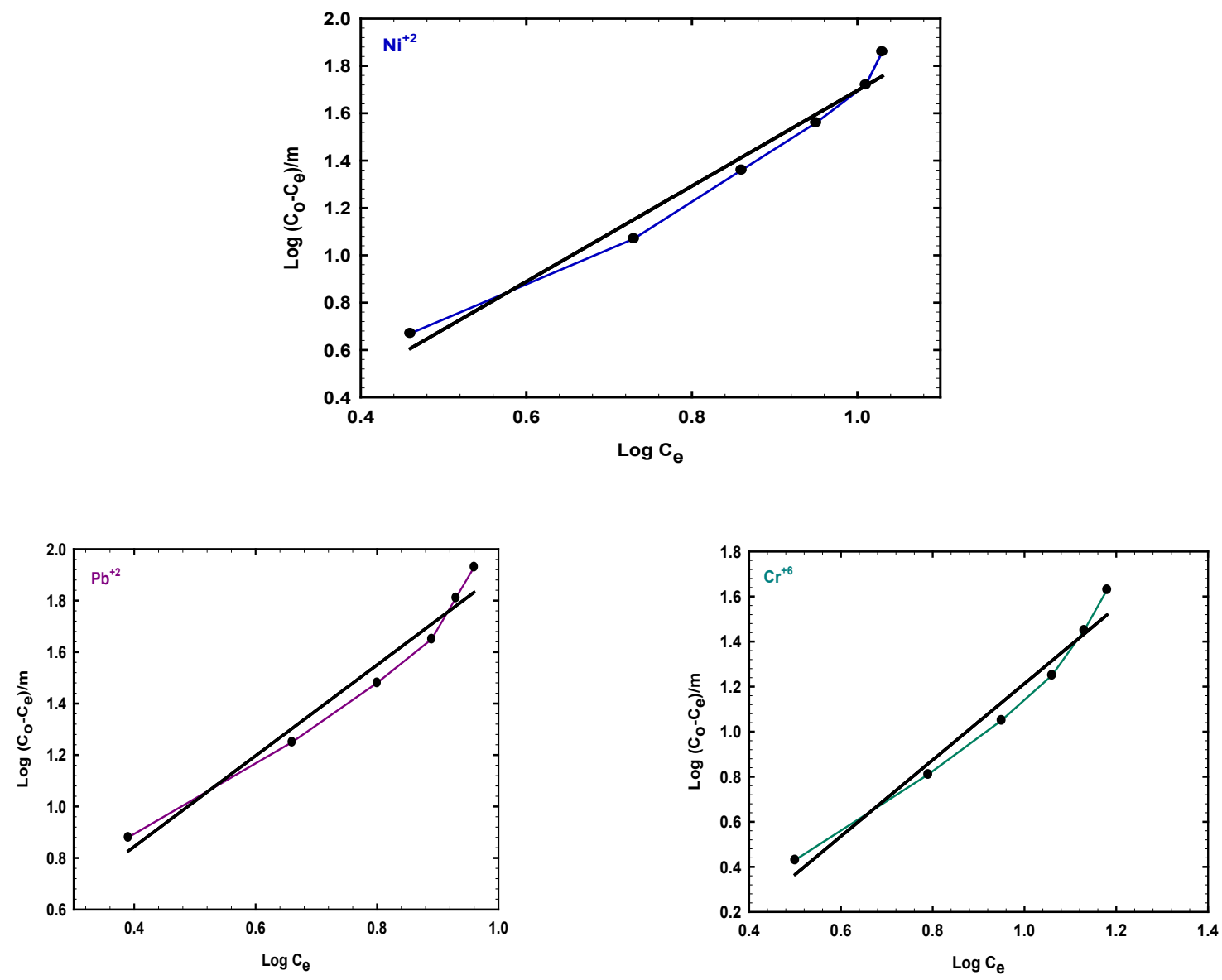

Fig. 8b. The Freundlich Isotherm for $\mathrm{Ni}, \mathrm{Pb}$, and $\mathrm{Cr}$, respectively.

$\mathrm{C}_{\mathrm{e}}$ is the equilibrium concentration (ppm), $\mathrm{m}$ is the amount of the used adsorbent materials $(\mathrm{g})$, and $\mathrm{K}$ and $1 / \mathrm{n}$ are Freundlich's constants. Plotting $\log \left(C_{o}-C_{e} / m\right)$ against $\log C_{e}$ gives a straight line, which indicates the applicability of Freundlich isotherm (Fig. 8). The constants $\mathrm{K}$ and $1 / \mathrm{n}$ for each metal could be determined from the slopes and intercepts of these produced lines and all parameters are listed in Table 2. On the other hand, it was found that the correlation $\mathrm{R}^{2}$ is less than 1 , which indicates that the obtained results are in a good agreement with Freundlich isotherm.

\section{Conclusion}

We showed in this paper that the clay minerals and activated carbon could be used as effective adsorbent materials for the treatment of contaminated water with heavy metals. It was found that the adsorption of heavy metals on clay-carbon mixture is dependent on the $\mathrm{pH}$, initial concentration, adsorbent dose and contact time. The ideal circumstances of heavy metals removal achieved from this study are $\mathrm{pH}$ range from 6.8 to 7.4, initial concentration of $100 \mathrm{ppm}$ and a mass loading of $5 \mathrm{~g}$ clay minerals and $2 \mathrm{~g}$ activated carbon. In addition, the correspondence of Freundlich adsorption isotherm fits well the investigational data. Hence, the adsorbent mixture of clay minerals and activated carbon could be useful for the economic treatment of wastewater contaminated with heavy metals.

\section{References}

1. Duman O., Tunc S. and Polat T. G., Appl. Clay Sci. 109-110, 22-32 (2015).

2. Duman O. and Ayranci E., Sep. Sci. Technol. 41, 3673-3692(2006).

3. Duman O. and Ayranci E., J. Hazard. Mater. 174, 359-367 (2010).

4. Ayranci E. and Duman O., Sep. Sci. Technol. 44, 3735-3752 (2009).

5. Ayranci E. and Duman O., Chem. Eng. J. 156, 7076 (2010). 
6. Duman O. and Ayranci E., J. Hazard. Mater. 176, 231-238 (2010).

7. Duman O., Tunc S. and Polat T.G., Microporous Mesoporous Mater. 210, 176-184 (2015).

8. Najua Delaila Tumin, Luqman Chuah A., Zawani Z. and Suraya Abdul Rashid, J. Eng. Sci. Tech., 3, $180-189$ (2008)

9. Kannan N., Veemaraj T., Glob. NEST J. 12, 197205 (2010).

10. Salehzadeh J., Leonardo J. of Sci. 23, 97-104 (2013).

11. Bernard E., Jimoh A. and Odigure J.O., Res. J. of Chem. Sci. 3, 3-9 (2013).

12. Miller R.W. and Donahue R.L., Soils: An Introduction To Soils And Plant Growth. PrenticeHall, Inc., Englewood Cliffs, N. J., USA (1992).

13. Prost R. and Yaron B. , Soc. Sci., 166, 880-894 (2001)

14. Castrilloa N., Mercado A. and Volzone C., Procedia Mat. Sci. 8, 391-396 (2015).

15. Sotelo J.L., Ovejero G., Rodríguez A. and García S.A.J., Chem. Eng. J. 228, 102-113 (2013).

16. Wu D., Zhu C., Chen Y., Zhu B., Yang Y., Wang Q. and Ye W., App. Clay Sci. 62-63, 87-93 (2012).

17. Bachir M., Salah M.M., El-fala B.Z. and Soulard M., Phys. Procedia 55, 356-366 (2014).

18. Kostka J. E., Dalton D. D., Skeleton H., Dollhopf S. and Stucki J. W., Applied and Environmental Microbiology, 68, 6256-6262 (2002).

19. Oades J. M., An introduction to organic matter in mineral soils. P.89-159. In J. B. Dixon and S.B. Weed (eds.): Minerals in Soil Environments. $2^{\text {nd }}$ edition. Soil Sci. Soc. Am., Madison, Wisconsin, USA (1989).

20. Toor M. and Jin B., Chem. Eng. J. 187, 79- 88 (2012).
21. Zhang H., Tong Z., Wei T. and Tang Y., App. Clay Sci. 65-66, 21-23 (2012).

22. Missana T., Garcia-Guttierez M., Alonso U., Physics and Chemistry of the Earth, 33, 156-162 (2008).

23. Andras, P, Lichy A., Kusnierova M., Krizani I, Ladomersky J., Ruskova J. and Hroncova E., Acta Montanistica Slovaca Rocnik 14, 127-142 (2009).

24. Haseena P. V., Padmavathy K. S., Rohit Krishnan P. and Madhu G., Procedia Technology 24, 733740 (2016)

25. Klute, A., Methods of Soil Analysis. Part 1: Physical and mineralogical methods. 2nd ed. Agron. Monogr. No. 9. ASA and SSSA, Madison, WI (1986).

26. Shama S. A. and Gad M.A., Portug Electrochim. Acta 28(4), 231-239 (2010).

27. DIN18123(1)BestimmungderKorngrößenverteilung Wiesbaden, pp. 273-284 (1998).

28. BS (British Standards Institution), Moisture content and index tests, vol. BS 1377, pp. 50-100 (London) (1975).

29. Mahvi A. H., Naghipour D., Vaezi F. and Nazmara S., Am. J. App. Sci., 2, 372-375 (2005).

30. Krishnan K. A. and Anirudhan T.S., Wat. S. A., 29, 147-156 (2003).

31. Gueu S., Yao B., Adouby K. and Ado G., J. of App. Sci. 6(13), 2789-2793 (2006).

32. Bradl H., Encyclopedia of Surf.\& Coll. Sci., 1-13 (2002).

33. Missana T., Garcia-Guttierez M. and Alonso U., Physics and Chemistry of the Earth, 33, 1, 156162 (2008).

(Received 11/9/2017; accepted 24/9/2017) 
دراسة مقارنه از الة المعادن الثقيلة من مخلفات المياه الصناعيه باستخدام الطمى و الكربون المنشط علي دفعه واحده ور تدفق مستمر

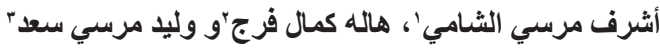

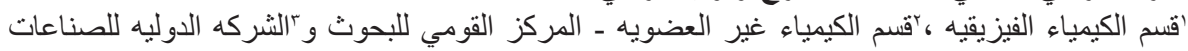

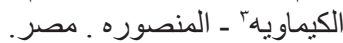

تم فى هذا البحث دراسة معالجة مخلفات المياه الصناعية الناتجه من الصناعات البتروليه باستخدام الطمي و الطئ

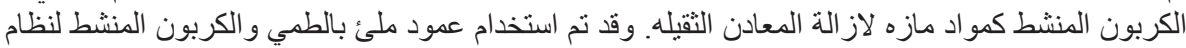

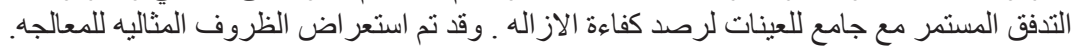

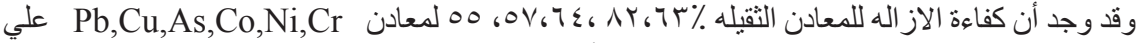

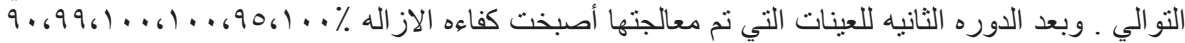

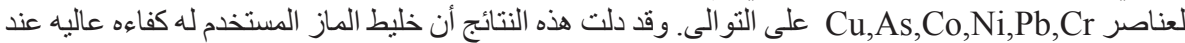
استخدامه لاز الة كاتيونات العناصر الثقيله من مخلفات المياه الصناعيه. 